\title{
The Impacts of Conceptual Change Text-based Concept Teaching on Various Variables
}

\author{
Barış Çaycı \\ Faculty of Education, Niğde Ömer Halisdemir University, Niğde, Turkey
}

Copyright $(2018$ by authors, all rights reserved. Authors agree that this article remains permanently open access under the terms of the Creative Commons Attribution License 4.0 International License

\begin{abstract}
In this study, the purpose of which is to investigate the effectiveness of conceptual change texts, the data was obtained through 'Concept Achievement Test' by Çalık and Ayas [17], 'Attitude Scale toward Conceptual Change Text' by Yalvaç [18] and 'Science Teaching Self-Efficacy Belief Instrument' by Enochs and Riggs [20]. The scales were conducted as pre-test before empiric process and post-test after empiric process. The study group consists of 112 teacher candidates studying at the 3 rd grade of Primary School Teaching Department at a state university. The study was designed and conducted within experimental design with pre-test and post-test control group. After a four-week research, the analysis of the data showed that the concept achievements, attitudes toward conceptual change texts and elementary science teaching self-efficacy beliefs of the teacher candidates who were given conceptual change texts based concept education were significantly higher than those of the teacher candidates who received traditional concept education without conceptual change texts.
\end{abstract}

Keywords Conceptual Change Texts, Concept Achievement, Attitude, Science Self-efficacy, Teacher Candidate

\section{Introduction}

One of the essential components in today's educational mentality, which is based on constructivist learning approach, is to teach the scientific concepts with a method that is suitable for the schematic structures in mind and that reshapes those structures during the meaningful and functional structuring process of scientific knowledge necessary for academic achievement. In other words; concepts, which are the building blocks of scientific knowledge, should be taught as meaningful bodily information for the learner, effective structures in problem solving process and through a method transferable to daily life so that learners become competent in the subject and their academic achievements improve. Because, whatever the discipline or its subject is, knowledge-based academic achievement depends on the learner's competency and success as to the concepts that constitute that knowledge.

Concepts are a knowledge structure which represents the changing common features of different objects and facts [1] and common names given to idea and object groups with similar features [2]. Concepts are the creators of even the simplest scientific knowledge. In brief, concepts are prerequisite for scientific knowledge, scientific theories and scientific laws, which means that science and scientific developments wouldn't exist without concepts.

The biggest obstacle against concepts of such high concern, which shape the world and technology of the future, is the instruction of them as concepts that are not taught through an effective, daily life-oriented and functional method can only form a meaningless pile of information. Conceptual change approach within the constructivist approach should be applied to give such a concept education.

Conceptual change approach is an alternative approach which encourages learners to pass from misconceptions to scientific concepts and is based on Piaget's assimilation, accommodation and homeostasis principles [3]. This approach claims that learners cannot learn the scientific concepts satisfactorily without correcting the misconceptions that they themselves have created or that are taught to them in that way.

The essential point of conceptual change approach is to prove learners why misconceptions are fallacies. In other words; to eradicate a misconception that has gained a strong place in a learner's mental construct and to replace it with the correct concept, it is necessary to prove both the misconception's incorrectness and its ineffectiveness in problem-solving. However, the proof required for misconception includes a process that consists of four components.

The above-mentioned components required for the proving and eradication of misconceptions are inefficacy, comprehensibility, rationality and efficiency $[4,5,6,7,8,9]$. Briefly stated; inefficacy, comprehensibility, rationality 
and efficiency are to prove the learner the inability of a misconception to solve a problem, to make the examples and features of the scientific concepts to be learned by the learner more comprehensible, to show that a problem that a misconception couldn't solve can be solved by the scientific concept that will replace the misconception and to prove that the newly learned scientific concept can solve all the other similar problems respectively.

There is a range of methods and techniques that detect learners' misconceptions and ensure the eradication of them by enabling the above-mentioned components during the conceptual change process. One of the strongest of them is the conceptual change texts, which were first developed by Wang and Andre [3]. Several researchers have then contributed to the improvement of those texts.

Conceptual change texts consist of four sections and include the components required for proving misconceptions. Demirbaş et al [10] states that these texts exemplify misconceptions, their reasons and the inefficiency of them in problem-solving process.

The basic difference between conceptual change texts and traditional texts is that conceptual change texts consist of questions that activate learners' prior concepts, prior knowledge and current misconceptions and include explanations, case studies, examples, visuals like images and/or pictures and scientific explanations that show what relevant misconceptions are and why they occur while traditional texts include only knowledge. Therefore, it can be stated that conceptual change texts have the characteristics of conceptual change approach principles. Besides, several researchers who have conducted studies on conceptual change texts $[3,5,11,12,13,14]$ have determined that these texts, in comparison with the traditional texts, are among the most effective ones in eradicating misconceptions and constructing scientific concepts meaningfully, permanently and functionally.

In a concept education process that has the principles of conceptual change approach and uses conceptual change texts, two strong models that proceed from samples to definition and are appropriate to modern concept education such as $5 \mathrm{E}$ and $7 \mathrm{E}$ are used. $5 \mathrm{E}$ model, which is a linear process in learning a new concept or enabling a more in-depth understanding of a familiar concept [15], is preferred in this study. The model consists of introduction, discovery, explanation, deepening and evaluation steps. It meets the inefficacy, comprehensibility, rationality and efficiency components of conceptual change process in the introduction and discovery steps, explanation step, deepening step and evaluation step respectively. On the other hand, conceptual change texts are used in all steps of $5 \mathrm{E}$ model. This situation shows that the avoidance of misconceptions and the effective construction of scientific concepts is a process consisting of 3 elements (conceptual change approach, 5E learning model, conceptual change texts).

This study consists of a four-week experimental process which includes prior knowledge and new knowledge association of constructivist approach in general. However, more specifically, conceptual change principles besides $5 \mathrm{E}$ learning model and conceptual change texts are used in the process that is based on the science subject 'solutions'. The study investigates whether teacher candidates got rid of their misconceptions about solutions and whether their conceptual achievements about solutions improved by learning new scientific concepts effectively at the end of the process. It also tries to find out whether they acquired positive attitudes towards the texts used in the process and whether their science teaching self-efficacies, which is an important emotional factor in science teaching efficacy, differed. Besides, teacher candidates both improved their knowledge about solutions and learned in practice how to use some approaches, models and techniques necessary for modern concept education. The research questions of the study are given below.

\subsection{The Purpose of the Study}

The purpose of the study is to investigate the effects of conceptual change texts-based instruction that is effective in a sufficient concept acquisition process on primary school teacher candidates' concept achievements, attitudes to conceptual change texts and beliefs in their science teaching self-efficacy. Following are the research questions of the study;

1. Do the teacher candidates' conceptual achievements, attitudes and science teaching self-efficacy beliefs differ significantly according to the pre-test and post-test scores of the experimental group?

2. Do the teacher candidates' conceptual achievements, attitudes and science teaching self-efficacy beliefs differ significantly according to the pre-test and post-test scores of the control group?

3. Do the teacher candidates' conceptual achievements, attitudes and science teaching self-efficacy beliefs of the teacher candidates in the experimental group differ significantly from those of the teacher candidates in the control group according to the post-test scores?

\section{Methodology and Material}

\subsection{Research Model}

The research is designed as experimental model, which is a research model in which the data to be observed are produced directly under the control of the researcher to discover cause-effect relations [16]. It is based on pre-test and post-test control group design, which has high scientific value as the most commonly used one among experimental models, to determine the effects of conceptual change texts-based instruction on different variables. The iconic view of the study is summarized in table 1 . 
Table 1. The Iconic View of the Experimental Design of the Research

\begin{tabular}{c|c|c|c}
\hline Groups & Pretest & Application & Posttest \\
\hline \multirow{2}{*}{ Experimental } & CAT & Conceptual Instruction & CAT \\
Group & ASTCCT & Based on Conceptual & ASTCCT \\
& STSEBI & Change Texts & STSEBI \\
\hline \multirow{3}{*}{ Control Group } & CAT & Traditional Conceptual & CAT \\
& ASTCCT & ASTCCT \\
& STSEBI & Instruction & STSEBI \\
\hline
\end{tabular}

Table 2. The Results of Independent t-test as to the CAT, ASTCCT and STSEBI Pre-test Scores of Experimental and Control Groups before the Empiric Process

\begin{tabular}{|c|c|c|c|c|c|c|c|}
\hline Scale & Groups & $\mathrm{N}$ & $\bar{X}$ & S & $\mathrm{t}$ & sd & $\mathrm{p}$ \\
\hline CAT & Experimental Control & $\begin{array}{l}59 \\
53\end{array}$ & $\begin{array}{l}10,41 \\
11,04\end{array}$ & $\begin{array}{l}3,08 \\
3,19\end{array}$ & $-1,065$ & 110 & $\begin{array}{c}.289 \\
p>0,05\end{array}$ \\
\hline ASTCCT & Experimental Control & $\begin{array}{l}59 \\
53 \\
\end{array}$ & $\begin{array}{l}71,54 \\
72,36 \\
\end{array}$ & $\begin{array}{l}7,14 \\
7,40 \\
\end{array}$ & $-0,594$ & 110 & $\begin{array}{c}.554 \\
p>0,05\end{array}$ \\
\hline STSEBI & Experimental Control & $\begin{array}{l}59 \\
53\end{array}$ & $\begin{array}{l}59,66 \\
58,04\end{array}$ & $\begin{array}{l}5,66 \\
4,27\end{array}$ & 1,725 & 110 & $\begin{array}{c}.087 \\
\mathrm{p}>0,05\end{array}$ \\
\hline
\end{tabular}

\subsection{Study Groups}

The research was conducted in the undergraduate program of the primary school teaching department at a Turkish state university in 2017-2018 spring term. There are two 3rd grade classes in the program. The reason for conducting the study with 3rd grade students is that primary school teacher candidates take science lessons at this grade. The study was conducted in spring term as the subjects related to conceptual instruction are taught in science lessons during that term.

The data obtained from the scales that were conducted as pre-test to both classes was analysed through independent t-test to determine whether the experimental and control groups were equal and the results of the analysis are given in table 2.

As shown in table 2, there is no significant difference between CAT pre-test scores $\left(\mathrm{t}_{(110)}=-1,065, \mathrm{p}>0,05\right)$, ASTCCT pre-test scores $\left(\mathrm{t}_{(110)}=-0,594, \mathrm{p}>0,05\right)$ and STSEBI pre-test scores $\left(\mathrm{t}_{(110)}=1,725, \mathrm{p}>0,05\right)$ of the experimental and control groups. As to the arithmetical means, it can be stated that both groups' conceptual achievements, attitudes towards conceptual change texts and science teaching self-efficacy beliefs are similar in general sense.

The results of the equality tests given to the experimental and control group classes may be summarized as;

- The researcher tried to ensure that the total teacher candidate numbers in both groups were as equal as possible. Accordingly, Class-A and Class-B consisted of 59 and 53 teacher candidates respectively.

- The data obtained from CAT, ASTCCT and STSEBI that were applied as pre-test before the empiric process showed that the conceptual achievements, attitudes and self-efficacy beliefs of the teacher candidates were similar.

- The classes were assigned as experimental and control groups through unbiased-random method.
Accordingly, Class-A was assigned as the experimental group and Class-B was assigned as the control group.

- The instructions that were appropriate to the approaches were carried out under the researcher's guidance through interaction with the teacher candidates at the same period of time (four weeks in total) in both groups.

\subsection{Data Collection Tools}

The data was collected through three different scales in this study. These scales are 'Concept Achievement Test' (CAT) which is used to determine the teacher candidates' levels of using the concepts in the science subject correctly and meaningfully, 'Attitude Scale toward Conceptual Change Text' (ASTCCT) whose purpose is to find out the teacher candidates' attitudes towards conceptual change texts used in concept education based on eradicating misconceptions and 'Science Teaching Self-Efficacy Belief Instrument' (STSEBI) which was developed to determine the teacher candidates' self-efficacy beliefs in science teaching.

\subsubsection{Concept Achievement Test (CAT)}

CAT is a test developed by Çalık and Ayas [17] and consists of 20 multiple-choice questions about solutions. The researchers received expert opinions for the content validity of the test. Construct validity of the test was analysed through item analysis and the reliability of the test was tested by Pearson Product-Moment and Spearman Brown. The average item difficulty, distinctiveness and reliability of the test were $0.50,0.51$ and 0.95 respectively. The validity and reliability analysis of the test indicated that the test could measure the concepts about solutions, or the conceptual knowledge of the participants about solutions, correctly and effectively. 


\subsubsection{Attitude Scale towards Conceptual Change Texts (ASTCCT)}

The original ASTCCT developed by Yalvaç [18] is a five-likert scale consisting of 25 items and its reliability co-efficient is 0.90 . The validity and reliability of the scale were tested by Konur and Ayas [19] again. In accordance with the results of these tests, 2 items were excluded from the original scale and it was found that the new version of the scale represented $39 \%$ of the total variance and its reliability co-efficient was 0.91 . The results of the study conducted by Konur and Ayas [19] with primary school teacher candidates revealed that the scale could measure teacher candidates' attitudes towards conceptual change texts consistently and reliably.

\subsubsection{Science Teaching Self-Efficacy Belief Instrument (STSEBI)}

STSEBI is a 23 -item scale with 2 dimensions that was developed by Enochs and Riggs [20]. The scale was adapted into Turkish by Bıkmaz [21] and after the validity and reliability analysis 2 items were excluded from the scale. Later, Çaycı [22] tested its validity and reliability again and reduced the items of the scale to 16 . It was concluded that the first dimension of the scale that consisted of 11 items the $24,29 \%$ of the total variance and the second dimension of the scale which included 5 items represented the 16,42 of the total variance. These results showed that the scale represented $40,71 \%$ in total. On the other hand, the Cronbach's Alpha reliability co-efficient of the scale was measured as 0,79 for the whole scale. Considering these results, it can be stated that STSEBI can test the science teaching self-efficacy beliefs of teacher candidates consistently and reliably within the determined factor structure.

\subsection{Process}

Before the instruction period, pre-tests were applied to the experimental and control groups first, which is of great importance in experimental studies. Then, post-tests were conducted after the four-week instruction to the experimental and control groups.

The subject to be taught in the instructional period was chosen as 'solutions'. The reason why 'solutions' was chosen is that it is a subject that primary school teachers teach their students and that it includes several concepts and categories, which makes it highly prone to contradictions in terms and misconceptions. The subject 'solutions' is within the matter subject, which is divided into two main topics; pure substances and mixtures. Pure substances are sub-grouped as elements and compounds while mixtures are classified as homogenous and heterogeneous mixtures. Solutions are among the homogenous mixtures.

The subject 'solutions' was divided into four units so that it could be studied thoroughly. These units are 'pure substances (elements and compounds), mixtures (mixtures, simple mixtures and solutions) and their properties' in the first week, 'types of mixtures and solutions and their properties' in the second week, 'dissolution and the factors affecting the pace of dissolution' in the third week and 'decomposition of solutions' in the last week. One week was allocated for every single unit and the subjects were taught in three course hours within their own weeks. Every course hour consisted of 45 minutes with ten-minute breaks between each lesson, which means that the time allocated for every unit was 135 minutes and the whole subject was taught in 540 minutes.

The lessons were taught with 59 teacher candidates in the experimental group and the instruction design was based on $5 \mathrm{E}$ conceptual instruction model, which contains the principles of conceptual change approach. The main purpose of the conceptual change approach is to help individuals get rid of misconceptions and to manage the process of acquiring new and scientific concepts meaningfully and permanently. The basic point in the approach is to prove individuals why misconceptions are misconceptions. Four conditions for that proof (inefficacy, comprehensibility, rationality and efficiency) are provided by $5 \mathrm{E}$ model. Conceptual change texts are a type of text that also includes these four conditions. In brief, the lessons with the experimental group were taught through conceptual change texts and 5E model.

Accordingly, the researcher determined the misconceptions of the teacher candidates about the subject of the week through grid and question and answer method, prepared conceptual change methods in accordance with the misconceptions reviewing the related literature and did the lessons on the basis of 5E model using those conceptual change texts.

The general plan of three-week lessons for every week is as following;

- The researcher uses question and answer method to trigger the misconceptions and teacher candidates' pre-concepts without giving scientific knowledge about the subject. This stage falls in the introduction stage of $5 \mathrm{E}$ model and the first stage of conceptual change texts, which is the questions section. It shouldn't be forgotten that these texts are sectional with four parts and every part is handed out to the participants as the related stage of the $5 \mathrm{E}$ model starts.

- The researcher then uses question-answer, direct instruction and case studies to make the teacher candidates think over the confusing misconceptions as to the subject, and find answers to the questions. This stage refers to the discovery stage and the second part of the conceptual change texts, in which the existing misconceptions are listed.

- After that, the researcher passes on to the explanation stage of $5 \mathrm{E}$ model and teaches the lesson by giving scientific knowledge through visuals, videos and materials related to the concepts of the related subject of the week. Meanwhile, the scientific explanations section is also applied as the fourth part of conceptual 
change texts. In addition, the researcher also tries to meet the second condition (comprehensibility) for proof, which is the basic principle of conceptual change approach.

- After the third step, the researcher passes on to the deepening stage of $5 \mathrm{E}$ model and starts the fourth step of the three-hour lesson process. In this stage, the reasons for the occurrence of misconceptions are discussed with the teacher candidates. It is observed that scientific concepts can solve problems while misconceptions cannot. In other words, the information in this part of the conceptual change texts is matched with the scientific explanations acquired by the teacher candidates in the previous steps, thus meeting the rationality as the third condition of the proof.

- Finally, the researcher passes on to the evaluation stage of $5 \mathrm{E}$ model both to provide the last condition for proof (efficiency) and to prove that not misconceptions but scientific concepts can solve some questions/problems/case studies making the teacher candidates solve them. Besides, the researcher determines whether misconceptions still exist through last evaluation activities and informs the teacher candidates.

Thanks to the design of the process and its content explained above, experimental group teacher candidates themselves are involved in the process and develop an understanding about how and why to get rid of misconceptions through conceptual change, $5 \mathrm{E}$ teaching model and the requirements of conceptual change texts. By this means, both field information (solutions) and teaching method and information (conceptual change approach, 5E model and conceptual change texts) are taught. In other words, the role and efficiency of conceptual change texts in concept teaching are proven.

On the other hand, control group teacher candidates receive education within a traditional sense of concept education that does not make use of conceptual change texts. The first lesson of three-hour courses every week starts with a process based on visual and materials by stating what the subject and its concepts to be taught are. Teacher candidates, who collect information about the subject and the concepts during the first lesson, get scientific explanations through expository instruction by the teacher and link that new information with the information gained during the previous lesson. They then test the information they have acquired through various problems and give feedback in the third lesson. The lessons end with question and answer activities in the control group as well.

As it can be understood from the explanations about the control group, teacher candidates in the control group will have difficulty in getting rid of misconceptions and won't be able to develop an understanding as to how and why to get rid of them because the instructions they have received do not have the principles and objectives of conceptual change approach. That's because the conceptual change texts, whose efficiency this study tries to prove, are used only in conceptual change approach, which has the nature of modern concept teaching in terms of both structure and content, and in such concept teaching models that put the principles of conceptual change approach into practice as $5 \mathrm{E}$ and $7 \mathrm{E}$ models. $5 \mathrm{E}$ model is preferred in this study.

\subsection{The Analysis of the Data}

The data were analysed through SPSS 24. The distribution normality of the data was tested through Kolmogorov-Smirnov test and the results of the test showed that variables had normal distribution by $95 \%$ reliability. In addition, the homogeneity of the variances was tested through Levene test and parametric tests were used in accordance with the results. Accordingly, 1st and 2nd sub-problems were tested through dependent t-test while 3rd sub-problem was tested through independent t-test.

\section{Findings}

This study in which the effects of conceptual change texts-based instruction on primary school teacher candidates' concept achievements, attitudes to conceptual change texts and beliefs in their science teaching self-efficacy is based on three sub-problems. The results of the analysis for these sub-problems are given below.

\subsection{Findings about the 1st Sub-problem}

The results of the analysis of the 1st sub-problem, which is expressed through the research question "Do the teacher candidates' conceptual achievements, attitudes and science teaching self-efficacy beliefs differ significantly according to the pre-test and post-test scores of the experimental group?" are given in Table 3.

Table 3. Dependent t-test Results of the CAT, ASTCCT, STSEBI Pre-test and Post-test Scores of the Experimental Group after the Empiric Process

\begin{tabular}{|c|c|c|c|c|c|c|c|}
\hline Scale & Treatment & $\mathrm{N}$ & $\bar{X}$ & $\mathrm{~S}$ & $\mathrm{t}$ & sd & $\mathrm{p}$ \\
\hline CAT & $\begin{array}{l}\text { Pretest } \\
\text { Posttest }\end{array}$ & $\begin{array}{l}59 \\
59\end{array}$ & $\begin{array}{l}10,41 \\
14,90\end{array}$ & $\begin{array}{l}3,08 \\
2,41\end{array}$ & $-12,544$ & 58 & $\begin{array}{c}.000 \\
\mathrm{p}<0,05\end{array}$ \\
\hline ASTCCT & $\begin{array}{l}\text { Pretest } \\
\text { Posttest }\end{array}$ & $\begin{array}{l}59 \\
59 \\
\end{array}$ & $\begin{array}{l}71,54 \\
96,73\end{array}$ & $\begin{array}{l}7,14 \\
9,82\end{array}$ & $-18,179$ & 58 & $\begin{array}{c}.000 \\
\mathrm{p}<0,05\end{array}$ \\
\hline STSEBI & $\begin{array}{c}\text { Pretest } \\
\text { Posttest }\end{array}$ & $\begin{array}{l}59 \\
59 \\
\end{array}$ & $\begin{array}{l}59,66 \\
62,86 \\
\end{array}$ & $\begin{array}{l}5,66 \\
6,46 \\
\end{array}$ & $-5,616$ & 58 & $\begin{array}{c}.000 \\
\mathrm{p}<0,05\end{array}$ \\
\hline
\end{tabular}


Table 4. Dependent t-test Results of the CAT, ASTCCT, STSEBI Pre-test and Post-test Scores of the Control Group after the Empiric Process

\begin{tabular}{|c|c|c|c|c|c|c|c|}
\hline Scale & Treatment & $\mathrm{N}$ & $\bar{X}$ & $\mathrm{~S}$ & $\mathrm{t}$ & $\mathrm{sd}$ & $\mathrm{p}$ \\
\hline CAT & $\begin{array}{l}\text { Pretest } \\
\text { Posttest }\end{array}$ & $\begin{array}{l}53 \\
53 \\
\end{array}$ & $\begin{array}{l}11,04 \\
12,89 \\
\end{array}$ & $\begin{array}{l}3,19 \\
3,02 \\
\end{array}$ & $-4,688$ & 52 & $\begin{array}{c}.000 \\
\mathrm{p}<0,05\end{array}$ \\
\hline ASTCCT & $\begin{array}{l}\text { Pretest } \\
\text { Posttest }\end{array}$ & $\begin{array}{l}53 \\
53 \\
\end{array}$ & $\begin{array}{l}72,36 \\
73,68 \\
\end{array}$ & $\begin{array}{l}7,40 \\
9,55 \\
\end{array}$ & $-1,008$ & 52 & $\begin{array}{c}.318 \\
\mathrm{p}>0,05\end{array}$ \\
\hline STSEBI & $\begin{array}{l}\text { Pretest } \\
\text { Posttest }\end{array}$ & $\begin{array}{l}53 \\
53\end{array}$ & $\begin{array}{l}58,04 \\
57,15\end{array}$ & $\begin{array}{l}4,27 \\
5,70\end{array}$ & 1,521 & 52 & $\begin{array}{c}.134 \\
\mathrm{p}>0,05\end{array}$ \\
\hline
\end{tabular}

Table 5. Independent t-test Results of the CAT, ASTCCT, STSEBI Pre-test and Post-test Scores of the Experimental and Control Groups after the Empiric Process

\begin{tabular}{|c|c|c|c|c|c|c|c|}
\hline Scales & Groups & $\mathrm{N}$ & $\bar{X}$ & S & $\mathrm{t}$ & $\mathrm{sd}$ & $\mathrm{p}$ \\
\hline CAT & $\begin{array}{c}\text { Experiment } \\
\text { Control }\end{array}$ & $\begin{array}{l}59 \\
53 \\
\end{array}$ & $\begin{array}{l}14,90 \\
12,89 \\
\end{array}$ & $\begin{array}{l}2,41 \\
3,02\end{array}$ & 3,915 & 110 & $\begin{array}{c}.000 \\
\mathrm{p}<0,05\end{array}$ \\
\hline ASTCCT & $\begin{array}{c}\text { Experiment } \\
\text { Control }\end{array}$ & $\begin{array}{l}59 \\
53 \\
\end{array}$ & $\begin{array}{l}96,73 \\
73,68 \\
\end{array}$ & $\begin{array}{l}9,82 \\
9,55\end{array}$ & 12,564 & 110 & $\begin{array}{c}.000 \\
\mathrm{p}<0,05\end{array}$ \\
\hline STSEBI & $\begin{array}{c}\text { Experiment } \\
\text { Control }\end{array}$ & $\begin{array}{l}59 \\
53\end{array}$ & $\begin{array}{l}62,86 \\
57,15\end{array}$ & $\begin{array}{l}6,46 \\
5,70\end{array}$ & 4,940 & 110 & $\begin{array}{c}.000 \\
p<0,05\end{array}$ \\
\hline
\end{tabular}

According to Table 3, following the concept teaching studies carried out with the conceptual change texts; significant differences are found in favor of posttest performed for CAT $\left(\mathrm{t}_{(58)}=-12,454 ; \mathrm{p}<0.05\right)$, for $\operatorname{ASTCCT}\left(\mathrm{t}_{(58)}=-18,179 ; \mathrm{p}<0.05\right)$, and for STSEBI $\left(\mathrm{t}_{(58)}=\right.$ $-5,616 ; p<0.05)$ in the experimental group.

The results given in table 3 show that conceptual change texts-based instruction resulted in positive and significant improvement on primary school teacher candidates' concept achievements, attitudes to conceptual change texts and beliefs in their science teaching self-efficacy

\subsection{Findings about the 2 nd Sub-problem}

The results of the analysis of the 2nd sub-problem, which is expressed through the research question "Do the teacher candidates' conceptual achievements, attitudes and science teaching self-efficacy beliefs differ significantly according to the pre-test and post-test scores of the control group?" are given in Table 4.

According to Table 4, a significant difference in favour of post-test for CAT $\left(\mathrm{t}_{(52)}=-4,688, \mathrm{p}<0,05\right)$ was found after the traditional concept education to the control group. On the other hand, the rise in favour of post-test for $\operatorname{ASTCCT}\left(\mathrm{t}_{(52)}=-1,008, \mathrm{p}>0,05\right)$ and the decrease in favour of post-test for STSEBI $\left(\mathrm{t}_{(52)}=1,521, \mathrm{p}>0,05\right) \mathrm{did}$ not lead to a significant difference.

These results indicate that traditional concept education causes a significant increase in the concept achievements of primary school teacher candidates while it does not lead to a significant difference in their attitudes towards conceptual change texts. Besides, although it does not cause a significant difference, it results in a certain extent of decrease in their science teaching self-efficacy levels.

\subsection{Findings about the 3rd Sub-problem}

The third and the most important sub-problem of the study is expressed as "Do the teacher candidates' concept achievements, attitudes and science teaching self-efficacy beliefs of the teacher candidates in the experimental group differ significantly from those of the teacher candidates in the control group according to the post-test scores?". The results of the analysis as to this sub-problem are given in Table 5.

Table 5 shows that there is a significant difference between the CAT post-test scores $\left(\mathrm{t}_{(110)}=3,915, \mathrm{p}<0,05\right)$, ASTCCT post-test scores $\left(\mathrm{t}_{(110)}=12,564, \mathrm{p}<0,05\right)$ and STSEBI post-test scores $\left(\mathrm{t}_{(110)}=4,94, \mathrm{p}<0,05\right)$ of experimental and control groups and the difference is in favour of the experimental group. Considering the arithmetic averages, it can be stated that the concept achievements, attitudes towards conceptual change texts and science teaching self-efficacy beliefs of the teacher candidates in the experimental group significantly increased compared to those of the teacher candidates in the control group.

\section{Conclusion and Discussion}

The main purpose of this study, whose study group consists of primary school teacher candidates, is to determine the efficiency of instruction conducted through conceptual change texts. The study, which was therefore planned and conducted as an experimental one including pre-test and post-test control group, investigated the effect of using conceptual change texts on the teacher candidates' concept achievements, attitudes towards conceptual change texts and science teaching self-efficacy beliefs. The results obtained after the research process, which focused on 'solutions' as the course subject, can be summarized as following;

- The concept achievements of the teacher candidates in the experimental group, who received an instruction appropriate to modern concept education 
approach in which conceptual change texts were used, are significantly higher than those of the teacher candidates in the control group $\left(\mathrm{t}_{(110)}=3,915, \mathrm{p}<\right.$ $0,05)$,

- The experimental group teacher candidates' attitudes towards conceptual change texts are significantly higher than the control group teacher candidates' attitudes $\left(\mathrm{t}_{(110)}=12,564, \mathrm{p}<0,05\right)$,

- The science teaching self-efficacy beliefs of the teacher candidates in the experimental group are significantly higher than those of the teacher candidates in the control group $\left(\mathrm{t}_{(110)}=4,94, \mathrm{p}<0,05\right)$.

The results as to concept achievement given above indicate that modern concept education, which enables the use of conceptual change texts, caused a significant increase in teacher candidates' concept achievements, which is an indicator of their efficiency in using the concepts about the subject and in solving related problems. In other words, conceptual change texts were proven quite effective in enhancing concept achievement. This result is supported with the finding that the average concept achievement in the experimental group $(\bar{X}=14,9)$ was higher than that in the control group $(\bar{X}=12,89)$.

On the other hand, the increase in the concept achievements of the learners is closely related to their abilities to get rid of the misconceptions, establish meaningful connections between the old and new concepts, replace the misconceptions with scientific concepts functionally, use the newly acquired concepts in problem solving process and transfer them to their daily lives.

This positive effect of conceptual change texts on concept achievement can be explained with the fact that those texts activate learners' prior knowledge about the concepts, allow connections between their old and new conceptual knowledge and enable the proof and its components that are required for the process of eradicating misconceptions and structuring the new scientific concepts as meaningful bodily information. The result of the study that shows a positive relation between the conceptual change texts and concept achievement as well as the elements related to concept achievement is supported with the result of several researches $[11,24,25,27,28,31,32$, $33,34,35]$.

The common result obtained in the studies by Wang and Andre [3], Chambers and Andre [5], Mikkila-Erdmann [12] and Alvermann and Hague [23] was that conceptual change texts were more successful and effective in improving concept achievement of students than the traditional types of texts including only information and questions. Also, Sungur et al. [14], Guzzetti et al [26] and Hynd et al [29] concluded that conceptual change texts supported with concept maps, discussion methods and demonstration method were more effective in enabling students to get rid of misconceptions and to improve their concept achievements.

In addition, the results of the studies by Demirbaş et al
[10], Kasap and Ültay [30] and Balcı et al [37] also show that the components of modern concept education increase concept achievement, which also corresponds to the result of this study.

Considering these three results in terms of attitudes towards conceptual change texts, it can be stated that teacher candidates who were constructed through conceptual change texts developed positive attitudes and thoughts towards the use of conceptual change texts in concept education processes. Because average attitude level was $\bar{X}=96,73$ in the experimental group while it was only $\bar{X}=73,68$ in the control group.

The increase in concept achievement with the use of conceptual change texts can be associated with the idea that teacher candidates develop positive attitudes towards conceptual change texts as they observe, in practice, how these texts are used in various stages of models of modern concept education processes and see how easily they are prepared and used. According to Fidan [36], attitudes are the acceptance and rejection tendencies of an individual to an element. They are not behaviours but psychological variables that shape behaviours. Thus, positive attitudes of teacher candidates towards conceptual change texts indicate that these texts are significant components in concept education.

The results of several studies on the positive attitudes of learners towards conceptual change texts and courses in which these texts are used as well as the teaching methods that make use of these texts correspond to the result of this study in terms of attitudes [15,24,38,39,40].

Konur and Ayas [19] revealed in their three-week study based on conceptual change texts about physical and chemical change that primary school candidates' attitudes towards these texts were high. Written reflections of the participants also supported those high level attitudes.

When analysed in terms of science teaching self-efficacy beliefs, the results of the study showed that science teaching self-efficacy levels of experimental group teacher candidates differed significantly and positively. The average self-efficacy level of the experimental group was $\bar{X}=62,86$ while that of the control group was $\bar{X}=57,15$.

One component of teacher self-efficacy, which is defined by Guskey and Passaro [41] as teachers' beliefs as to their self-confidence in their ability to instruct their students effectively, is science teaching self-efficacy, which is expressed as teachers' judgment about their abilities to conduct science education effectively and efficiently and to improve student achievement [42]. Teacher candidates observe in practice they both improve their concept achievements and get rid of misconceptions easily by using conceptual change texts, which is an important explanation of the increase in their science teaching self-efficacy beliefs as an affective feature like attitude.

Çaycı [43] conducted a study to investigate the relation between concept achievement and self-efficacy and found 
a positive significant relation between students' self-efficacy beliefs and their concept achievement levels. According to the results of the study, students' self-efficacy levels accounted for $34 \%$ of the total variance of students' concept achievements, which means that conceptual change texts increase concept achievement, thus improving their self-efficacy beliefs positively.

Considering the results of this study and the related studies in literature mentioned above, it can be suggested not to handle concept education like teaching information. Rather; concept education should involve conceptual change approach, modern concept education mentality, models such as $5 \mathrm{E}$ and $7 \mathrm{E}$, techniques like conceptual change texts and methods that establish connection between the concepts and daily life and are supported with visual materials. Because, rise in academic achievement and positive developments in affective introduction characteristics will ensure the desired quality in educational environments.

\section{REFERENCES}

[1] G. Ülgen. Concept Development. Theories and Applications, Pegem Press, Ankara, 2001.

[2] F. Kaptan. Teaching Science, Milli Eğitim Press, İstanbul, 1999.

[3] T. Wang, T. Andre. Conceptual change text versus traditional text and application questions versus no questions in learning about electricity, Contemporary Educational Psychology, Vol. 16, No. 2, pp. 103-116, 1991.

[4] M. E. Beeth. Facilitating conceptual change learning: the need for teachers to support metacognition, Journal of Science Teacher Education, Vol. 9, No. 1, pp. 49-61, 1998.

[5] S. K. Chambers, T. Andre. Gender, prior knowledge, interest and experience in electricity and conceptual change text manipulations in learning about direct current, Journal of Research in Science Teaching, Vol. 34, No. 2, pp. 107-123, 1997.

[6] M. G. Hewson, P. W. Hewson. Effect of instruction using students' prior knowledge and conceptual change strategies on science learning. Journal of Research in Science Teaching, Vol. 20, No. 8, pp. 731-743, 1983.

[7] G. J. Posner, K. A. Strike, P. W. Hewson, W. A. Gertzog. Accommodation of a scientific conception: toward a theory of conceptual change, Science Education, Vol. 66, No. 2, pp. 211-227, 1982.

[8] E. L. Smith, T. D. Blakeslee, C. W. Anderson. Teaching strategies associated with conceptual change learning in science, Journal of Research in Science Teaching, Vol. 30, No. 2, pp. 111-126, 1993.

[9] K. A. Strike, G. J. Posner. A Revisionist Theory of Conceptual Change. Philosophy of Science, Cognitive Psychology and Educational Theory and Practice, R. A. Duschl, R. J. Hamilton. (Editors), State University of New York Press, Albany, 1992.
[10] M. Demirbaş, G. Tanrıverdi, D. Altınıșık, Y. Sahintürk. The impact of conceptual change texts on the elimination of misconceptions of science teacher candidates about the subject of solutions, Sakarya University Journal of Education, Vol. 1, No. 2, pp. 52-69, 2011.

[11] C. Alparslan, C. Tekkaya, Ö. Geban. Using the conceptual change instruction to improve learning, Journal of Biological Education, Vol. 37, No. 3, pp. 133-137, 2003.

[12] M. Mikkila-Erdmann. Improving conceptual change concerning photosynthesis through text design, Learning and Instruction, Vol. 11, No. 3, pp. 241-257, 2001.

[13] T. Pınarbaşı, N. Canpolat. Conceptual change approach in science education-II: conceptual change texts, Gazi University Kastamonu Education Journal, Vol. 10, No. 2, pp. 281-286, 2002.

[14] S. Sungur, C. Tekkaya, Ö. Geban. The contribution of conceptual change texts accompanied by concept mapping to students' understanding of the human circulatory system, School Science and Mathematics, Vol. 101, No. 2, pp. 91-101, 2001.

[15] T. Özsevgeç. Determining effectiveness of student guiding material based on the 5E model in "force and motion" unit, Turkish Science Education, Vol. 3, No. 2, pp. 36-48, 2006.

[16] N. Karasar. Scientific Research Method, Nobel Press, Ankara, 2000.

[17] M. Çalık, A. Ayas. Preparation and implementation of concept achievement test in solutions, Pamukkale University Journal of Education, Vol. 2, No. 14, pp. 1-17, 2003.

[18] B. Yalvaç. Effect of instruction on students' understanding of electric current concept using conceptual change text and 6th grade, Unpublished Master Thesis, Middle East Technical University, Ankara, 1998.

[19] K. B. Konur, A. Ayas. Attitudes of the pre-service primary teachers' towards the conceptual change texts in the subject of physical and chemical change, Ahi Evran University Kirşehir Journal of the Faculty of Education, Vol. 18, No. 3, pp. 971-991, 2017.

[20] L. G. Enochs, I. M. Riggs. Further development of an elementary science teaching efficacy belief instrument: a preservice elementary scale, School Science and Mathematics, Vol. 90, No. 8, pp. 694-706, 1990.

[21] F. H. B1kmaz. Self-efficacy belief instrument in science teaching, Educational Sciences and Practice, Vol. 1, No. 2, pp. 197-210, 2002.

[22] B. Çayc1. The effect of technology based course material use on the science teaching self-efficacy beliefs of elementary pre-service teachers, The New Educational Review, Vol. 27, No. 1, pp. 221 -231, 2012.

[23] D. E. Alvermann, S. A. Hague. Comprehension of counterintuitive science text: effects of prior knowledge and text structure, Journal of Educational Research, Vol. 82, No. 4, pp. 197-202, 1989.

[24] N. Canpolat. Investigation of effectiveness of conceptual change approach on understanding of chemical equilibrium concepts, Unpublished Phd Thesis, Atatürk University, Erzurum, 2002. 
[25] Ö. Geban, G. Bayır. Effect of conceptual change approach on students' understanding of chemical change and conservation of matter, Hacettepe University Journal of Education, No. 19, pp. 79-84, 2000.

[26] B. J. Guzzetti, W. O. Williams, S. A. Skeels, S. M. Wu. Influence of text structure on learning counterintuitive physics concepts, Journal of Research in Science Teaching, Vol. 34, No. 7, pp. 701-719, 1997.

[27] N. Gürefe, S. H. Yarar, B. N. Pazarbaşı, H. Es. The effect of conceptual change texts on understanding of height concept of secondary school 5 th class students, International Journal of Educational Studies in Mathematics, Vol. 1, No. 1, pp. 58-68, 2014.

[28] C. R. Hynd, J. Y. Mcwhorter, V. L. Phares, C. W. Suttles. The role of instructional variables in conceptual change in high school physics topics, Journal of Research in Science Teaching, Vol. 31, No. 9, pp. 933-946, 1994.

[29] C. Hynd, D. Alvermann, G. Qian. Preservice elementary school teachers' conceptual change about projectile motion: refutation text, demonstration, affective factors and relevance, Science Education, Vol. 81, No. 1, pp. 1-27, 1997.

[30] G. Kasap, N. Ültay. To determine the effect of the activities based on conceptual change approach on students' conceptual understanding of floating-sinking objects, Kastamonu Education Journal, Vol. 22, No. 2, pp. 455-472, 2014.

[31] T. Pınarbaşı. Investigations of effectiveness of conceptual change approach on understanding of solubility concepts, Unpublished Phd Thesis, Atatürk University, Erzurum, 2002.

[32] Ö. Sarı Ay, C. Aydoğdu. The effect of conceptual change texts in the misconceptions identified removal in the unit of states of matter and heat, Hacettepe University Journal of Education, Vol. 30, No. 2, pp. 99-111, 2015.

[33] A. Şeker. Facilitating conceptual change in atom, molecule, ion and matter, Unpublished Master Thesis, Middle East Technical University, Ankara, 2006.

[34] S. S. Tarım. Comparison of the effectiveness of the conceptual change of the analogies and conceptual change texts used in the elimination of the alternative concepts of students in terms of acids and bases, Unpublished Master Thesis, Pamukkale University, Denizli, 2017.

[35] N. Topuz. The effect of conceptual change approach and cooperative learning method on the students' science achievement, attitude towards science and the level of ability to associate concepts with daily life, Unpublished Master Thesis, Trakya University, Edirne, 2014.

[36] N. Fidan. Learning and Teaching in School, Alkım Press, Ankara, 1985.

[37] S. Balc1. Improving 8th grade students' understanding of photosynthesis and respiration in plants by using $5 \mathrm{E}$ learning cycle and conceptual change text, Unpublished Master Thesis, Middle East Technical University, Ankara, 2005.

[38] O. Çardak. The identification of misconceptions of high freshmen on the variety and classification of living things and correction of them through concepts maps, Unpublished Phd Thesis, Selçuk University, Konya, 2002.

[39] B. Günay. Conceptual change text oriented instruction to facilitate conceptual change in atoms and molecules, Unpublished Master Thesis, Middle East Technical University, Ankara, 2005.

[40] S. Sevim. Preparation and application of conceptual change texts on solution and chemical bonding concepts, Unpublished Phd Thesis, Karadeniz Technical University, Trabzon, 2007.

[41] T. R. Guskey. P. D. Passaro. Teacher efficacy: a study of construct dimensions, American Educational Research Journal, Vol. 31, No. 3, pp. 627-643, 1994.

[42] A. Akbaş, Ö. Çelikkaleli. The examination of elementary pre-service teachers' self-efficacy beliefs in science teaching in terms of gender, education type and universities, Mersin University Journal of the Faculty of Education, Vol. 2, No. 1, pp. 98-110, 2006.

B. Çayc1. The relationship between elementary school students' self-efficacy beliefs towards science and technology and their concept achievements, Ahi Evran University Kırşehir Journal of the Faculty of Education, Vol. 14, No. 2, pp. 305-324, 2013. 